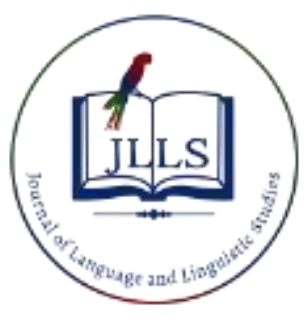

\title{
Using Kahoot as a skill improvement technique in pronunciation
}

\begin{abstract}
Nurcihan Yürük a * (iD
${ }^{a}$ Selçuk University, Deparment of Translation and Interpretation, Konya, 42250, Turkey

\section{APA Citation:}

Yürük, N. (2020). Using Kahoot as a skill improvement technique in pronunciation. Journal of Language and Linguistic Studies, 16(1), 137153. Doi: $10.17263 /$ jlls. 712669

Submission Date:04./12/2019

Acceptance Date:04./02/2020

Abstract

Pronunciation is one of the main problems in language teaching and learning and it gets little attention. Most of students underestimate the importance of pronunciation considering that pronunciation is less important than other aspects of language. Many researchers investigated the weakness of pronunciation among students in all stages. However, there is still a strong need to develop pronunciation of foreign language students. This study aims to investigate the effectiveness of using Kahoot application for developing EFL pronunciation and conducted with second year students at advanced level from Translation and Interpretation Department at Selçuk University in Turkey. A diagnostic test provided in a pronunciation course material was used in order to determine mispronouncing sounds. The study followed the two groups (control and experimental) with pre-post-test design. The pre-test was administered to the students of both groups at the beginning. After the administration of the pretest, for instruction session, the control group followed the activities in the course material and experimental group was taught using Kahoot application for the same activities. Then, the post-test was administered to both groups. The results were statistically analyzed (t-test) and the findings revealed that the EFL pronunciation skills of the experimental group were developed as a result of using Kahoot application. It is recommended that Kahoot application can be used in different educational stages for developing EFL pronunciation skills.
\end{abstract}

C 2020 JLLS and the Authors - Published by JLLS.

Keywords: Kahoot application; pronunciation skills

\section{Introduction}

Pronunciation is one of the most difficult skills that needs lots time and effort to acquire in order to be improved (Aliaga García, 2007; Martínez-Flor et al. 2006; Pourhosein, 2016). Pronunciation is one of the basic requirements of learner's competence and it also requires a place in language instruction. Learners' pronunciation levels play a significant role in language learning because it may promote or hinder language learning process (Pourhosein, 2016). During instruction process, learners should be provided with courses and materials that help them improve their pronunciation. Morley (1991) stated that the main goal of this type of instruction is making learners achieve an intelligible pronunciation

\footnotetext{
${ }^{*}$ Corresponding author. Tel.: +0-530-344-48-54

E-mail address: nurcihanbasibek@yahoo.com
} 
level to be a competent language learner in communication. Morley (1991) emphasized that learners should develop functional intelligibility, functional communicability, increased self-confidence, the speech monitoring abilities, and speech modification strategies. However, pronunciation instruction is sometimes neglected in language teaching (Pourhosein, 2016). According to Yates and Zielinski (2009), pronunciation has a key role in learning so it should be paid much attention to pronunciation and instruction as well. Teachers must have the responsibility to present the general rules and principles toward intelligible pronunciation to their EFL learners by teaching the new sounds, words, sentences, and phrases and arranging appropriate materials for learners to learn English pronunciation easily and effectively.

Teaching pronunciation is prominent in foreign language teaching. In spite of this, pronunciation has somehow become the most neglected and excluded component of language teaching and learning. It is ignored within the English as a foreign / second language (EFL/ESL) classroom context, teacher training programs and course materials. However, it should be viewed as an important part of language instruction that is incorporated into classroom activities (Pourhosein, 2016). In spite of the importance of the EFL pronunciation skills and the need for enhancing them among students, many of them tended to ignore many aspects of pronunciation, including sounds, intonation, pausing, linking and rhythm (Pardede, 2018). Thus, there is a need for an effective program for developing some EFL pronunciation skills among learners, especially for problematic sounds that do not exist in Turkish language. So, the following study aimed at examining the effectiveness of using Kahoot in developing EFL pronunciation skills.

\subsection{Literature review}

Pronunciation is an essential part of communication and without correct pronunciation nobody can talk about the existence of efficient communication. In foreign language classes the focus is generally on grammar and vocabulary and this makes learners become skilful in listening and reading. As communication is the main goal for many foreign language learners, it is true to state that learners should be careful about their pronunciation; pay utmost attention to its correct production; and try to improve their overall pronunciation skills (Çakır \& Baytar, 2014). For many learners to communicate in target language, there is no need to have an accurate pronunciation if the message is understood by the receiver. Therefore, learners may think that learning pronunciation is a waste of time.

Harmer (2001) states that many language teachers do not pay enough attention to English pronunciation. Also, some of the teachers think that pronunciation is too difficult and monotonous to study for learners (Harmer, 2001). Harmer (2001) states that teachers do not pay enough attention to pronunciation because of the lack of high quality, suitable teaching and learning materials, and the lack of time to practice. Some teachers believe that there is no need to teach correct pronunciation with a particular instruction because their students can acquire it incidentally. Native-like pronunciation may be an ideal goal for language proficiency but some of the learners may not have proficiency in performing native-like pronunciation. So, intelligibility is a logical aim for many of the learners. Therefore, pronunciation instruction has some realistic aims that need to be emphasized in order to develop communicative competence. According to Wrembel (2002), these aims are 1) functional intelligibility-developing spoken language that is easy to understand for listeners; 2) functional communicability-developing spoken language that meets communicative needs; 3) increased selfconfidence-developing a positive self-image; and 4) speech-monitoring abilities and speech modification strategies-that will allow students to develop intelligibility, communicability and confidence outside the classroom. In order to fulfill these aims, teachers should encourage their learners to study pronunciation severely and help them learn to pronounce sounds correctly. If students do not practice good pronunciation from the beginning of their learning process, they may have problems 
during the whole learning process of pronunciation and their errors become fossilized. Therefore, this may damage learners' overall success. Therefore, this may damage learners' overall success. Factors Affecting the Pronunciation of EFL Learners

Above all, there are many factors affecting pronunciation learning. Kenworthy (1987) has identified six main factors affecting pronunciation learning. The first one that affects pronunciation learning is native language factor deriving from phonemic differences of learner's mother tongue. The second factor is the age factor related to the biological timetable for learning. Also, the amount of exposure to target language plays a crucial role on pronunciation. Personality type and phonetic ability are the other important factors that have influence on pronunciation learning. As for other aspects of language, motivation is an important factor that affects pronunciation learning.

\subsubsection{The Native Language Factor}

Learners of a foreign language speak that language in different accents and that is called "foreign accent" that derives from learner's native language (Avery \& Ehrlich, 1987:9). This is also known as mother tongue interference. Phonemic differences between languages cause a target language to be spoken with a foreign accent and these foreign accents have the sound characteristics of the learners' native language. It is undeniable that language constitutes the biggest part of a culture, thus it is inevitable that there must be native language influence in the pronunciation of the target language.

Speakers of Turkish language have difficulty in pronouncing some English words and sounds which are not found in their native language that is why Turkish learners encounter pronunciation difficulties with the words that include those sounds never obtain a native-like accent, so they produce those sounds under the influence of native language (Hişmanoğlu, 2007). The following table shows the sounds that may be found problematic to pronounce by Turkish speakers of English:

Table 1. Problematic sounds for Turkish speakers of English

\begin{tabular}{|c|c|c|c|}
\hline Consonant & Keyword & Vowel & Keyword \\
\hline$\theta$ & things & av & about \\
\hline д & they & OU & although \\
\hline $\mathrm{n}$ & young & $æ$ & accents \\
\hline W & without & ə & adults \\
\hline $\mathrm{r}$ & repeat & 12 & clear \\
\hline
\end{tabular}

While learning foreign language learning, the effect of the native language on foreign language inevitable. However, a well-trained English teacher in phonetics and phonology can diminish the negative transfers of sounds to a greater extent. So, s/he should use specially prepared pronunciation teaching techniques. Then, the non-native English teachers are struggling with the negative interference from the mother tongue of the students in all their teaching lives, and they should do so for a decent teaching practice.

\subsubsection{The Age Factor}

Age is one of the most important factors that affects learning of the pronunciation of a foreign language. If someone pronounces second language with a native-like accent, s/he must have probably started to learn it during their childhood. For example, if young children are exposed to more than one language before the age of puberty, they seem to acquire all languages equally well since it has been claimed that children are better at learning than adults. As Krashen $(1988 ; 43)$ mentioned learners who begin to exposure to a second language during childhood generally acquire higher second language 
proficiency than those beginning as adults. The critical age hypothesis claims that there is a biological timetable for language learning, but it is widely discussed (Brown, 1997:42). Obviously, foreign language teaching scholars have outlined many views about the critical age hypothesis. It may be concluded that children are better in learning the language in short run when teaching pronunciation process started in puberty because it has been claimed that beyond puberty it is quite difficult to teach the learners to acquire a language with a native-like language.

\subsubsection{The Amount of Exposure}

If the learners have been living in an English-speaking country or community that they will be surrounded by the target language, or a country where English is the second language, then the learners will have many opportunities to listen to and to use the target language. However, if the learners have been living in a non-English speaking country, they do not have the advantage to be exposed to target language. So these learners will have no chance or opportunity to use the target language in a real-life setting. Therefore, it is impossible to mention about the existence of communication and this makes language learning difficult. For learners who do not have the chance to be in an English-speaking environment except their classrooms, focused-listening is the possible way to be satisfied with. However, it is clear that teaching correct and accurate pronunciation by just asking students to listen to artificial listening courses carried out in the classrooms is not enough to become proficient in pronunciation. Nevertheless, Kenworthy (1987:6) mentions that exposure can be a contributory factor, but it cannot be a whole and necessary factor for the development of pronunciation. If a learner is aware of the necessity of being exposed to the target language, s/he should make use of its opportunities. If the learner does that, s/he will be more successful in case of improving his/her pronunciation. The best ways of being exposed would be native speakers, videos, shows, films, CDs, radio or TV programs, computer assisted language teaching programs, and etc. Also, the amount of exposure with an optimum dose is crucial and it must make the students creative and active, not passive and dull.

\subsubsection{Phonetic Ability}

It is believed that some people have a better ear capacity for foreign language than other people. For example, they can discriminate two sounds more accurately and imitate sounds better than the others. These people are accepted as the ones who have phonetic abilities. This phonetic ability affects the development of learner's pronunciation. Nonetheless, it does not mean that people who have a better phonetic ability will be successful but the others won't be successful. Language aptitude exists in many people, but its degree shows diversity. Besides the factors mentioned above, the influence of age must be stated as an efficient factor for phonetic ability because learners may lose some of their abilities when they become older, so it can be difficult for them to pronounce the target language with a native or near native-like accent. The poor phonetic ability can be improved by the attempts of foreign language teachers. There are several devices to cure the poor pronunciation of the learners like the phonetic labs and remedial pronunciation teaching techniques. Those learners must not be discoursed but must be treated meticulously.

\subsubsection{Personality and Attitude}

Personality type of the learner is an important factor that affects the pronunciation level of learners. For example, shy or introvert students do not want to take part in classroom activities, so they cannot find any opportunities to make practice and to make use of phonological and/or phonetic activities. On the other hand, courageous or extrovert students have more chance to improve their pronunciation. Also, the attitude of the learners towards target language and culture has an effective role in pronunciation learning. If the learner has good attitudes for the target culture, s/he can easily develop more accurate, native-like accents. If the learners have some prejudices on the target language and its society, this event 
will influence his/her approach to the language. Thus, personality features and attitudes of the learners are also decisive in the learning of pronunciation.

\subsubsection{Motivation}

Motivation is the key factor to learn the target language. According to Brown (1997:114-15) the motivation is thought of as an inner drive, impulse, emotion, or desire that moves one to a particular action. When pronunciation is taken into account, a highly motivated learner has a better pronunciation performance compared to others. S/he is able to develop a concern for pronunciation, and become more eager to take part in the activities and pay more attention to discriminate the sounds of the target language resulting with producing better utterances. Motivation can be divided into two basic types: instrumental and integrative motivation (Brown, 1997: 115-117). Instrumental motivation refers to the instrumental goals such as furthering a career, reading some kinds of materials, translation, etc. An integrative motivation is the one which is employed when the learners want themselves to be in the culture of the second language group, to identify themselves with and become part of the society. Teachers need to be aware of student motivation to meet particular needs of the learners. Therefore, pronunciation teaching must be directed according to the needs, expectations, attitudes, intelligence, etc. of the learners. At the same time, motivation can be achieved by paying attention to the learners' concern for pronunciation because learners generally are not aware of that the way they speech is full of irritation and misunderstanding for the hearer.

Teachers should focus on the needs of their learners rather than generalize the teaching of pronunciation, especially when they are teaching groups of speakers of a given language as in this particular research context where all the students are native speakers of Turkish. Consequently, these students are very likely to share most of the common pronunciation problems. Then, FL teachers need to be aware of this and integrate this knowledge into classroom settings. Underhill (2005) and Griffiths (2011) have stated that teaching pronunciation has been neglected by teachers. They claimed that when pronunciation is studied or focused on in the classroom it tends to deal with specific pronunciation problems that happen in the precise moment of student performance. Therefore, it is important for teachers to create well-developed plans to address pronunciation problems in the best possible way. To sum up, teachers need to be aware of what pronunciation entails so that they can work on those areas that may be problematic due to learners' native language background.

In order to improve learners' pronunciation, there are a lot of useful suggestions both for teachers. First of all, teachers should determine learners' needs and problems in pronunciation. Depending on their needs, teachers should prepare some appropriate materials for learners to reduce their pronunciation problems (Shahzada, 2012) by incorporating pronunciation in other language activities to adapt learners to the sound systems of a new language and overcome learners' affective problems related to the learning a language (Rasekhi Kolokdaragh, 2010). In classroom setting, teachers prefer to speak clearly and slowly in their pronunciation classes that makes learners improve their pronunciation by listening to them carefully (Bradley-Bennett, 2007). So, learners become convinced that slow speech with correct pronunciation is much better than fast speech with wrong pronunciation and learners understand that intelligibility is more important than fast speech (Rasekhi Kolokdaragh, 2010). To familiarize learners to different accents and dialects teachers should present examples from different varieties of pronunciation (Rasekhi Kolokdaragh, 2010). Teacher's role in class should be like a speech coach of pronunciation by giving feedback to their learners and encouraging them to improve their pronunciation (Thanasoulas, 2002). Also, teachers should benefit from computer technologies such as different kinds of software programs and applications in classes to help their learners improve their pronunciation (Rasekhi Kolokdaragh, 2010). 
As technology has become more readily available to foreign language learning and teaching, teachers have attempted to use it in many ways to improve learners' pronunciation (Aguilar,3339). Neri, Cucchiarini and Strik (2013) claimed that there are a lot of benefits of computer assisted pronunciation instruction that cannot be found in traditional teaching approaches. Learners have the chance to access to an unlimited input through using technology. It also provides them with individualized feedback automatically. So, an online game is one of the most useful application both for learners and teachers that bring technology in classroom setting to help learners trigger learning process.

\subsection{Online Games in Foreign Language Classes}

An online game is a classroom response system which creates an engaging learning environment, through a game based digital pedagogy. It is an easy-to-use blended learning platform which operates with any internet-enabled device that helps making the classroom and the learning process fun, inclusive and engaging. It helps turning the classroom environment into an interactive and encouraging environment. It also helps learners feel as if they are just playing a game and they do not feel the anxiety of an actual learning environment.

Plumb and LaRosa (2017) stated that online games are educational applications that depend on student response system and they are up to date technologies with some advantages including being free, easy and engaging. They can be used by teachers to create three types of activities: quizzes, discussions and surveys. Also, they do not require that students have to create an account to participate in any kind of the activities because teachers do that. They are compatible with any smartphone, tablet or computer, gives instant feedback and improve the students' excitement and engagement. Online games have also some advantages for the teachers. They help instructors when they want to download, review and save learners' results and they can create quizzes, discussion questions and surveys and it helps also in adjusting the response time (Plumb \& LaRosa, 2017).

Online games can help students and learners create a new way of assessing their knowledge. These games with different types of activities such as quizzes, discussions and surveys can create an increase in the students' attitudes towards what they learn as well as their participation in the class and the learning process as a whole (Omar, 2017). Wang and Lieberoth (2016) stated that an online game is an educational tool for creating quizzes with the ability to add audio and video materials such as pictures, audio files and Youtube videos to the questions. It also enables the teacher to publish and share the quiz made by the teachers as well as edit others' quizzes.

There are a number of studies which investigated the effectiveness of using online games and one of the most popular online games is Kahoot application. Wang (2015) carried out a quasi-experimental design, comparing students who were exposed to Kahoot! in a single motivational lecture versus students where Kahoot! was used in every lecture for five months. Results indicated that the competitive nature of Kahoot! buffered against a wear off effect. It therefore seems like a promising tool to adjust teaching to learners' levels of knowledge, and in promoting active learning in a lecture setting. Yürük (2019) conducted a study related to use Kahoot application as a review activity for vocabulary learning to gather information on students' perceptions about this application included in educational process. Findings of the study indicate that students were able to engage actively in the lessons and they were able to master the target language vocabulary effectively and enjoy learning English using games.

Siegle (2015) added that teachers can select and determine the amount of time given to each question. Learners join the game through a game code and can create their names or even their nick names. When all the learners join the game and are ready for playing the game, the teacher can just click on start now to start the game. As the teacher starts to display questions on the screen, the learners begin clicking on the right answer and at the end the teacher can present a list of all the participants as well as 
their responses. Discussions at Kahoot has a little bit different style. The teacher can create only one question or only one topic and with no right or wrong answer and there are no points put intentionally for the question but there is a limited period of time which can be used during debate as well as any oral skill. Similarly, surveys on Kahoot do not have a specific answer which is wrong or right and the survey may include more than one question (Graham, 2015).

Bicen and Kocakoyun (2018) conducted a research to find which application in gamification is preferred by students and the results revealed that Kahoot was the most preferred application by students. Another study was conducted by Medina and Hurtado (2017) to explore the use of Kahoot on developing the learning of vocabulary in an English class. The results showed that using Kahoot increased the learners' engagement, interaction and motivation as well as the vocabulary acquisition. In another study, Licorish, George, Owen and Daniel (2017) investigated the effect Kahoot on engaging students during lectures. The findings revealed that the use of Kahoot enriches the quality of student learning in the classroom as well as the high effect on engagement, classroom dynamics, motivation and learning experience. With this in mind, this research aims to answer the following questions:

\subsection{Research questions}

1.Which sounds are problematic for second year students of the department of English Translation and Interpretation?

2. Does using Kahoot as a pronunciation development activity in instructional process have a significant effect on pronunciation development?

\section{Method}

When the effects of technology on foreign language learning and teaching are taken into consideration, the important role of technology could not be neglected (Yürük, 2019). So, at this point, Kahoot can be applied on the track of this purpose. This study is about an online free application called Kahoot that can be used to make learners engage foreign language learning process more effectively, actively and interestingly and can be accessed by teachers to use in foreign language classrooms. The aim of the study is to demonstrate Kahoot can be used as a pronunciation improvement tool in foreign language classrooms and to gather information on students' perceptions about this application included in educational process.

\subsection{Participants}

This study is conducted with second year undergraduate students at advanced level from Translation and Interpretation and English Language and Literature Departments at Selçuk University in Turkey. It includes 60 participants and 36 of the participants were female and the rest of them were male. The students ranged between 18-22 years of age. All the participants attended preparatory classes in their first year at the university.

\subsection{Instruments}

The diagnostic test provided for the participants was a reading material from the course material by Heinle \& Heinle Well-Said Pronunciation for Clear Communication (Grand, L., 2000) (App.A.) including possible problematic sounds for students which do not exist in their native language. The pretest and post-test of the study were also taken from the same course material (App.B). For the instruction session of the study, in order to develop the pronunciation skills of the students, activities from the book 
English Pronunciation in Use, (Hancock, M. \& Donna, S. 2012) were applied (App.C). The study was conducted with two groups as control and experimental groups. Pronunciation activities of the book were designed according to the groups attaining to the study. For the control group, the flow of the activities of the book were followed. On the other hand, the same activities were designed by the researcher on the Kahoot platform for the experimental group (App.D).

\subsection{Data collection and analysis}

At the beginning of the study, the researcher gave the diagnostic test to the participants of the study in order to determine the problematic sounds that were pronounced by the participants before implementing the instruction process. The voices of the participants were recorded by the researcher while they were reading the text in the diagnostic test and then, these recordings were evaluated by the researcher and two experts from Translation and Interpretation Department of Selçuk University in order to find out the problematic sounds pronounced by the participants. These recordings were evaluated as absolutely True or absolutely False according to the performances of the participants regarding problematic sounds. The evaluation process of diagnostic test took four days for both the control and the experimental groups. After that, participants were divided as control (30) and experimental (30) groups. Then, the pre-test of the study was administered to the participants. For the experimental section of the study, basic pronunciation instruction activities from the book were given only to control group (App.C.) and Kahoot activities on problematic sounds were given to experimental group on Kahoot platform (App. D). The pre-test of the study was given to participants in both control and experiment groups after the instruction process as the post-test to find out whether there was a significant difference between the groups in terms of their development. The results of the pre-test and post-test were statistically analyzed (t-test) and the findings of the post-test revealed that the pronunciation skills related to problematic sounds of the experimental group were developed as a result of using Kahoot application.

\section{Results}

The overall aim of using Kahoot platform was to develop pronunciation skills of second year students enrolled in the Translation and Interpretation Department of Selçuk University. After the implication of the pre-test, the post-test of the study was implied to both control experimental groups in order to measure the effectiveness of using Kahoot platform during instructional process and a t-test was used to find out whether there was a significant difference between the groups both for pre-test and post-test results.

The diagnostic test was applied to the participants both in control and experimental groups. The results of the diagnostic test showed that most of the students had some problems in pronouncing the English sounds which do not exist in their native language (Table 2).

Table 2. Percentages of Participants Regarding Mispronounced Sounds

\begin{tabular}{clllll}
\hline Consonant & Keyword & $\%$ & Vowel & Keyword & $\%$ \\
\hline$\theta$ & things & $\mathbf{6 7}$ & av & about & $\mathbf{7 2}$ \\
ə & they & $\mathbf{7 7}$ & ov & although & $\mathbf{6 3}$ \\
D & young & $\mathbf{9 0}$ & x & accents & $\mathbf{9 2}$ \\
W & without & $\mathbf{8 3}$ & ə2 & adults & $\mathbf{8 5}$ \\
r & repeat & $\mathbf{8 5}$ & 10 & clear & $\mathbf{8 7}$
\end{tabular}


According to the results of the pre-test of the study, $\mathrm{p}$ value equals to 0,5262. By conventional criteria, this difference is considered to be not statistically significant. It showed that group selection was random and neither of the groups was advantaged at the beginning of the study.

Table 3. Pre-Test Results

\begin{tabular}{lcrrrrrrr}
\hline Groups & $\mathrm{N}$ & Mean & $\mathrm{SD}$ & $\mathrm{SEM}$ & $\mathrm{df}$ & $\mathrm{t}$ & \multicolumn{2}{c}{$\mathrm{p}$} \\
\hline Experimental & 30 & 0,79 & 1,11 & 0,18 & 58 & 0,6511 & 0,5262 \\
Control & 30 & 0,64 & 0,79 & 0,16 & 58 & 0,6511 & 0,5262 \\
\hline
\end{tabular}

As mentioned above, the t-test is used to compare the mean scores of the participants on the post assessment of the control and experimental groups. Table 4 presents the mean scores of control and experimental groups.

Table 4. Post-Test Results

\begin{tabular}{|c|c|c|c|c|c|c|c|c|c|}
\hline Groups & $\mathrm{N}$ & Mean & SD & SEM & $\mathrm{df}$ & $\mathrm{t}$ & $\mathrm{p}$ & & \\
\hline Experimental & & 30 & 13,91 & 3,21 & 0,53 & 58 & 6,0742 & Less than & \\
\hline Control & & 30 & 10,13 & 3,79 & 0,61 & 58 & 6,0742 & Less than & 0,0001 \\
\hline
\end{tabular}

Table 4 indicates that mean scores for post-test showed differences between the experimental and control groups. T-test calculations were carried out in order to see the difference of the means of the two groups. According to the t-test results, $\mathrm{p}$ value is less than 0,0001 . By conventional criteria, this difference is considered to be extremely statistically significant. According to the results of the study, the pronunciation skills of the participants in the experimental group were developed comparing to the control group as a result of using of Kahoot platform.

\section{Discussion}

Before the implementation of Kahoot platform, according to results of the diagnostic test of the study, most of the participants were found to lack accurate pronunciation and have many problems in pronouncing different words. The results showed that many of the participants have some difficulties in pronouncing the sounds that are not existed in their native language. For the second year students in Translation and Interpretation Department, the pronunciation of problematic sounds deriving from their native language can be cured by using Kahoot platform. At the end of the implementation process, participants in experimental group demonstrated more improvement in their pronunciation skills than the participants in control group. According to the results of the study, it can be deduced that Kahoot platform as a pronunciation development activity contributed to improve participants' pronunciation skills. It is understood that the significant differences found in favor of the experimental group according to the post-test results. These results have proved the effectiveness Kahoot Platform as a pronunciation development activity.

Also, Kahoot platform provides participants immediate feedback related to their performances. The researcher and the participants could follow their overall performances. By using the Kahoot platform, 
it is possible to determine the opinions of the participants related to usage of the application as a report (Figure 1).

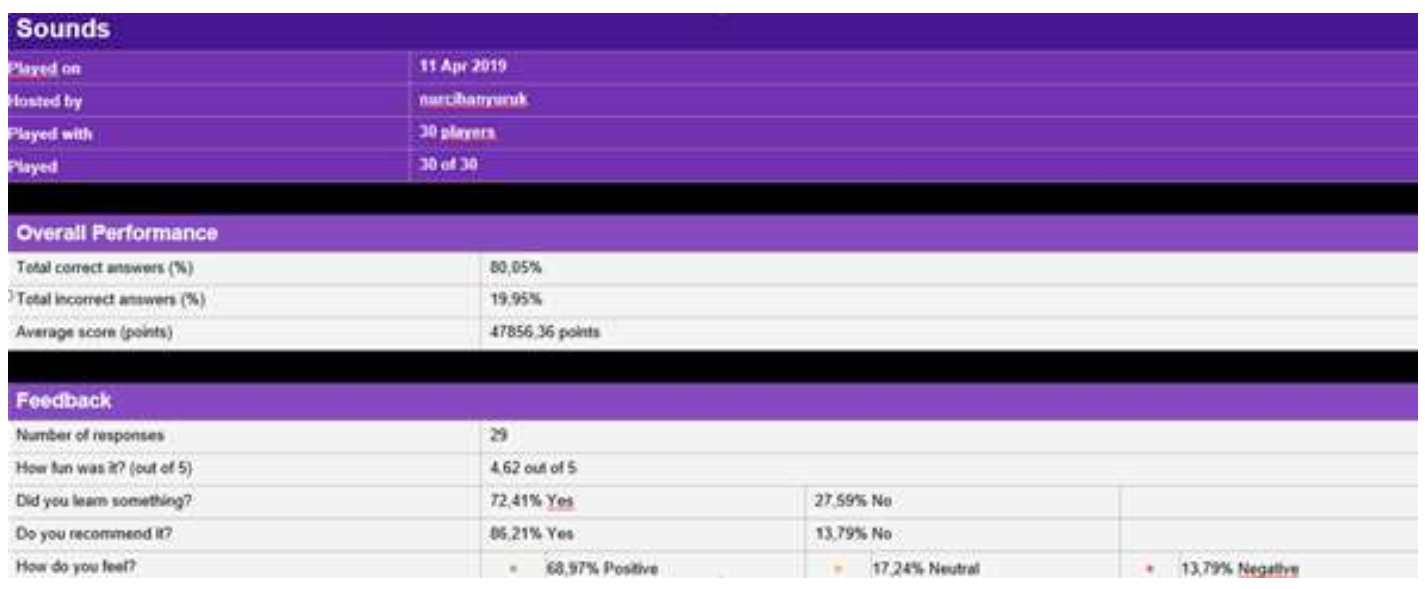

Figure 1. Opinions of the Participants related to Usage of Kahoot

The above report page taken from Kahoot application shows that most of the participants in the experimental group find the application fun (4.62 out of 5). Also, $72.41 \%$ of the participants declared that they learned something with the help of the application. Most of the participants have positive attitudes towards the application $(68.97 \%)$.

\section{Conclusions}

Kahoot is an excellent choice for teaching students due to the easy access to mobile devices, availability of Wi-Fi, and students' affinity for computer games. Tools like Kahoot create positive energy, support exploration, and add fun to the educational setting by increasing comprehension and motivation. Perhaps most significantly, the use of applications like Kahoot increases student engagement by appealing to all students, especially introverted and shy ones, combining both a cooperative fast-paced learning environment and friendly competition (Kapp, 2012). ELearning applications including the features of games are not sometimes approved and are not believed to be the result of serious work or worthy of attention. However, the present study showed that Kahoot! reinforces the effort and desire of the students to engage learning, this eLearning platform can provide an environment that supports learning and adds active participation in the classroom.

Kahoot platform also contains some other advantages like the ability to download, review, and save students" results; a "ghost mode" feature allows students to take quizzes multiple times and compete against themselves for better scores; and a setting to allow instructors to adjust the response time from 5 seconds to 120 seconds. There are also some disadvantages about which teachers and students should be aware. There is a limit on the number of characters you can use in questions and responses; and teachers cannot ask open-ended questions or receive open-ended responses. Overall, utilizing Kahoot was a positive experience that imbued classes with activity and focus and provided a way for all students to participate and contribute to the learning environment.

\section{Ethics Committee Approval}

The author confirms that this study does not need ethics committee approval. 


\section{References}

Aliaga García, C. (2007). The Role of Phonetic Training in L2 Speech Learning. Proceedings of the Phonetics Teaching and Learning Conference (PTLC2007), University College, London. Available at http://www.phon.ucl.ac.uk/ptlc/ptlc2007_web_procindex.html.

Avery, P. \& Ehrlich, S. (1987). Preliminary Considerations in the Teaching of Pronunciation. London: TESL Center.

Bicen, H. \& Kocakoyun, S. (2018). Perceptions of Students for Gamification Approach: Kahoot as a Case Study, IJET, 13(2).

Bradley-Bennett, K. (2007). Teaching Pronunciation: An Independent Course Study for Adult English as a Second Language learners. Retrieved from: http://hcot.ir/wpcontent/uploads/2014/09/TeachingPronunciation.pdf

Brown, D.H. (1997). Principles of Language Learning and Teaching. (3rd ed.) New Jersey: Prentice Hall Regents.

Çakır, İ. \& B. Baytar, B. (2014). Foreign language learners' views on the importance of learning the target language pronunciation, Journal of Language and Linguistic Studies, 10(1) 99-110.

Graham, K. (2015). TechMatters: Getting into Kahoot! (s): Exploring a game-based learning system to enhance student learning. LOEX Quarterly, 42(3), 6-7. Retrieved from http://commons.emich.edu/loexquarterly/vol42/iss3/4.

Grand, L. (2000). Well Said: Pronunciation for Clear Communication. (3rd ed.) Heinle Cengage Learning.

Griffiths, B. (2011). Integrating Pronunciation into Classroom activities. British Council \& BBC. Retrieved from http://www.teachingenglish.org.uk/articles/integrating-pronunciation-classroomactivities

Hancock, M. \& Donna, S. (2012). English Pronunciation in Use: Intermediate Second Edition Selfstudy and Classroom Use, CUP.

Harmer, J. (2001). The Practice of English Language Teaching. London: Longman.

Hişmanoğlu, M. (2007). The [ $\mathrm{\jmath}$ ] and [ Ơ ] Contrast as a Fossilized Pronunciation Error of Turkish Learners of English and Solutions to the Problem, Journal of Language and Linguistic Studies, $3(1)$.

Kapp, K. (2012). The Gamification of Learning and Instruction. San Francisco, CA: Pfeiffer.

Kenworthy (1987). Teaching English Pronunciation, Longman handbooks for language teachers, London and New York: Longman.

Krashen, S.D. (1988). Second Language Acquisition and Second Language Learning. New York: Prentice Hall Regents.

Licorish, S.A., George, J.L., Owen, H.E. \& Daniel, B. (2017). “Go Kahoot!” enriching classroom engagement, motivation and learning experience with games. In Chen, W. et al. (Eds.), Proceedings of the 36th International Conference on Computers in Education. New Zealand: Asia-Pacific Society for Computers in Education.

Martínez-Flor, A., Usó-Juan, E., \& Alcón Soler, E. (2006). Towards Acquiring Communicative Competence through Speaking. In Usó-Juan, E., \& Martínez-Flor, A. (eds) Current Trends in the 
Development and Teaching of the Four Language Skills. Berlin: Mouton de Gruyter, 139-157. [DOI:10.1515/9783110197778.3.139]

Medina, E.G.L., \& Hurtado, C.P.R. (2017). Kahoot! A Digital tool for learning vocabulary in a language classroom. Revista Publicando, 4(12).

Morley, J. (1991). The Pronunciation Component in Teaching English to Speakers of Other Languages. TESOL Quarterly, 25(1), 51-74. [DOI:10.2307/3586981]

Neri, A., Cucchiarini, C., \& Strik, H. (2013). Feedback in Computer assisted pronunciation training: when technology meets pedagogy in proceedings of CALL conference "CALL professionals and the future of CALL research", Antwerp, Belgium.

Omar, N.N. (2017). The effectiveness of Kahoot application towards student's good feedback practice. PEOPLE: International Journal of Social Sciences, 3(2).

Pardede, P. (2018). Improving EFL Students' English Pronunciation by Using the Explicit Teaching Approach, Journal of English Teaching, 4(3). [DOI: 10.33541//vol4iss3pp143].

Plump, C. M. \& LaRosa, J. (2017). Using Kahoot! In the classroom to create engagement and active learning: A game based technology solution for eLearning novices, Management Teaching Review, 2(2), 151-158.

Pourhosein G., (2016) Why is Pronunciation So Difficult to Learn? English Language Teaching 4(3) [DOI: 10.5539/elt. v4n3p74].

Rasekhi Kolokdaragh, V. (2010). ESL/EFL Learners' Perception of Their Pronunciation Needs and Strategies. 41st Annual State CATESOL Conference in Santa Clara, CA, April 23.

Rosell-Aguilar, F. (2007). Top of the Pods - In search of a podcasting "podagogy" for language learning. Computer Assisted Language Learning, 20(5) pp. 471-492.

Shahzada, G. (2012). Views of the Teachers Regarding the Students' Poor Pronunciation in English Language. Journal of Educational and Social Research, 2(1), 309-316. [DOI: 10.5901/jesr.2012.02.01.309].

Siegle, D. (2015). Technology: Learning can be fun and games. Gifted Child Today, 38(3), 192.

Thanasoulas, D. (2002). Motivation and Motivating in the Foreign Language Classroom. The Internet TESL Journal, 8(11), retrieved from October 2016, http://iteslj.org/Articles/ThanasoulasMotivation.html.

Underhill, A. (2005). Sound foundations: Learning and teaching pronunciation. (2nd ed.). Oxford, UK: Macmillan.

Wang, A. (2015). The wear out effect of a game-based student response system. Computers \& Education, 82, 217-227. [DOI:10.1016/j.compedu].

Wang, A. I., \& Lieberoth, A. (2016). The effect of points and audio on concentration, engagement, enjoyment, learning, motivation, and classroom dynamics using Kahoot! Connolly, T. \& L. Boyle (red.), Proceedings from the 10th European Conference of Game Based Learning (737-748). Reading, UK: Academic Conferences and Publishing International Limited.

Wrembel, M. (2002). New Perspectives on Pronunciation Teaching. In W. Sobkowiak and E. WaniekKlimczak. Dydaktyka Fonetyki Języka Obcego na Poziomie Licencjackim, Neofilologia II: Zeszyty Naukowe PWSZ, 173-183. 
Yates, L., \& Zielinski, B. (2009). Give It a Go: Teaching Pronunciation to Adults. Sydney, Australia: AMEPRC. Available: http://www.ameprc.mq.edu.au/resources/classroom_resources/give_it_a_go.

Yürük, N. (2019) Edutainment: Using Kahoot! As A Review Activity in Foreign Language Classrooms. Journal of Educational Technology \& Online Learning, 2(2). http://dergipark.gov.tr/jetol. [DOI: 10.31681/jetol.557518].

\section{Appendices}

\section{Appendix A. Diagnostic test of the Study}

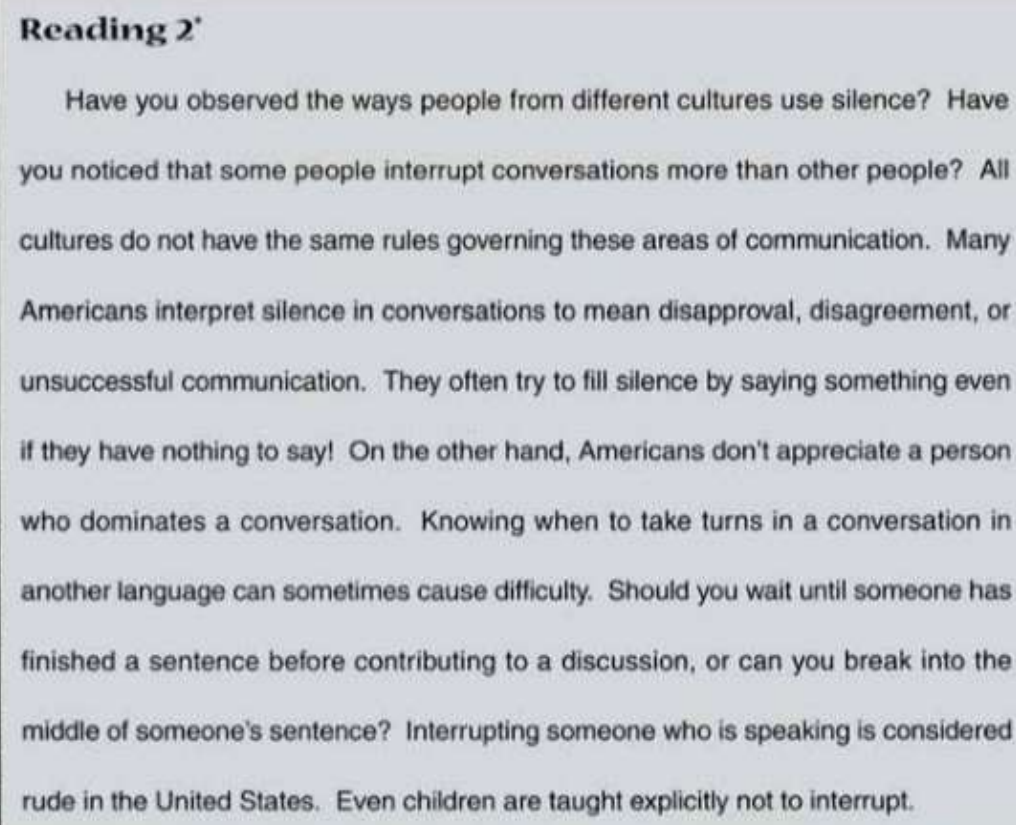

"From Deena A. Levine and Mara B. Adelman, Beyond Language: Intercultural Communication for English as a Second Language (Englewood Cifts, N.J.: Prentice Hall, 1982), p. 23. Reprinted with permission. 


\section{Reading $3^{*}$}

Edward T. Hall is a famous anthropologist who thinks that different cultures have different outlooks on time, space, and personal relationships. He classifies cultures along a continuum ranging from high context to low context. In high-context cultures, the circumstances surrounding a message carry more meaning than the message itself. For example, if an individual negotiates a business agreement, the reputation of the family is considered. Verbal promises are trusted, so there is little papenwork. What about low-context cultures? In low-context cultures, the words themselves are more important than the context. Social and family connections are not always regarded. Because the contract itself is the most important part of an agreement, the agreement might generate a lot of legal paperwork. Can you think of other examples of how cultural differences might lead to miscommunication?

"Information adapted from Edward T. Hall, The Hidden Dimension (Anchor Books, 1990).

\section{Appendix B. Pre-test and Post-test of the Study}

\section{Reading 1}

Have you ever watched young children practice the sounds of the language they are learning? They imitate, repeat, and sing consonant and vowel combinations without effort. For young children, learning to speak a language is natural and automatic. No one would suspect that complex learning is occurring. For adult

learners, however, pronunciation of a new language is not automatic. It presents an unusual challenge. Why is pronunciation progress in adults more limited? Some researchers say the reasons are biological or physical. Others say they are social or cultural. Although many questions are still unanswered, it is important to realize two things about clear speaking. First, pronunciation improvement might be difficult, but it is possible. Second, adults can learn to communicate clearly in English without losing their accents or their identification with their native cultures. 


\section{Appendix C. Instruction Material for Control Group}

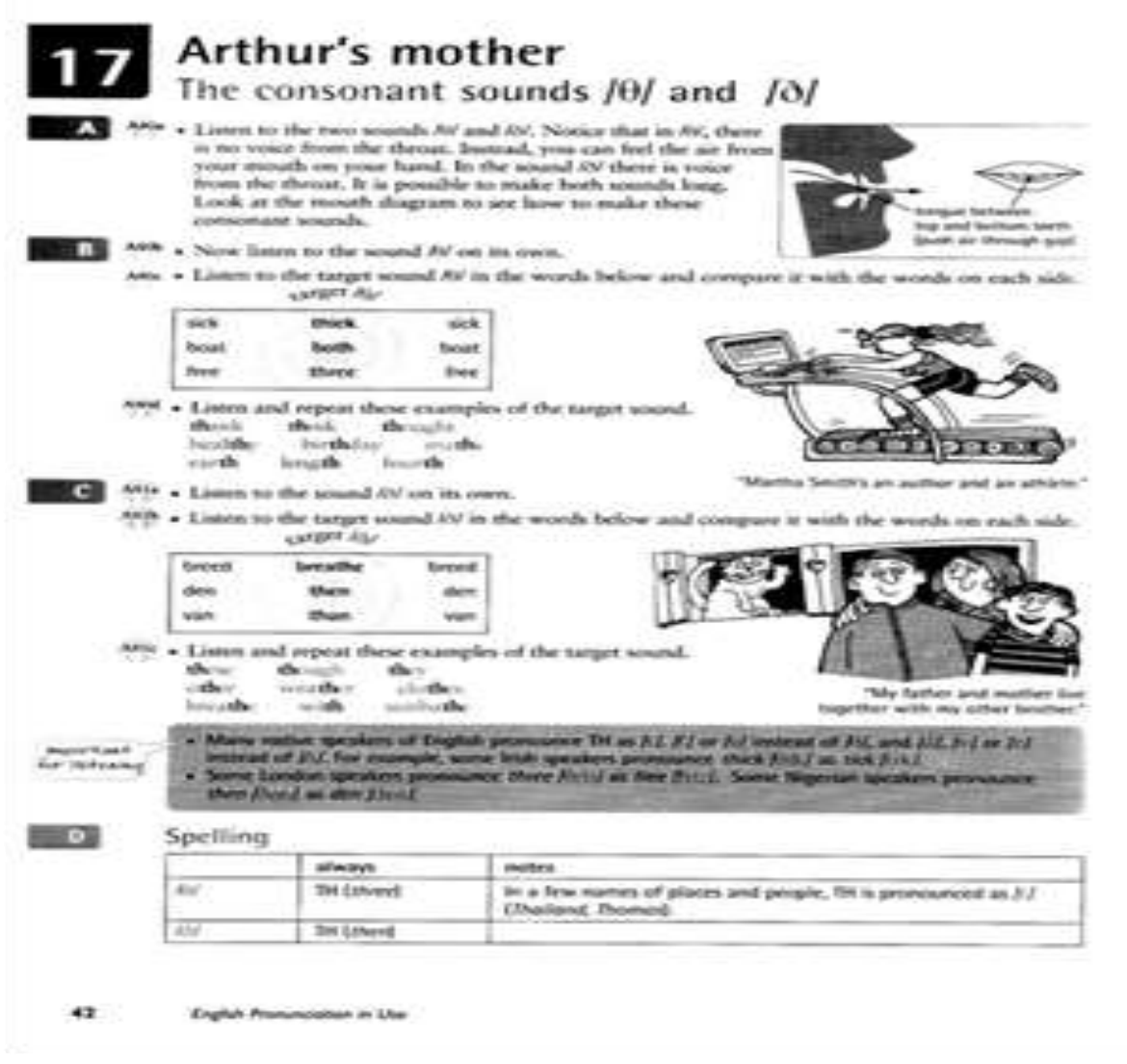




\section{Exercises}

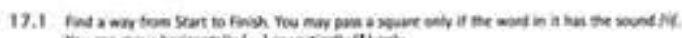

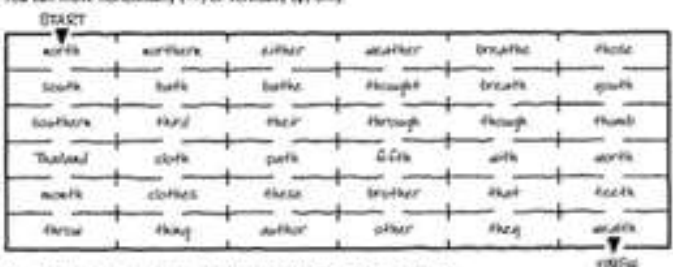

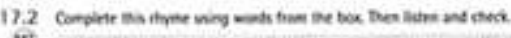

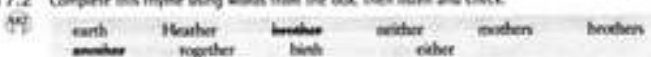

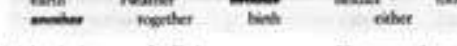

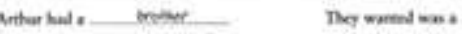

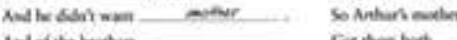

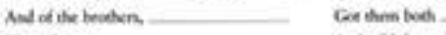

Wumed viater - And sid itom al pood

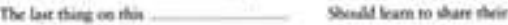

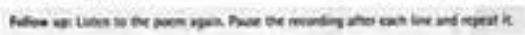

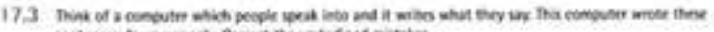

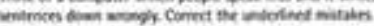

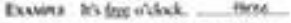

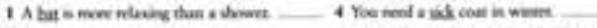

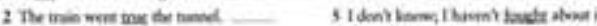

1 Deat wak on to in in war fin o Ma maner ef lit and dat.

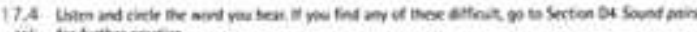

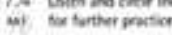

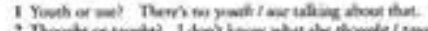

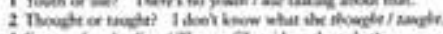

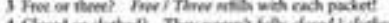

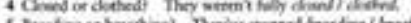

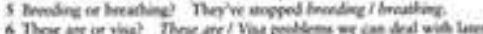

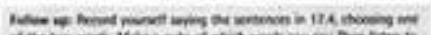

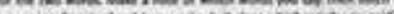

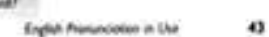

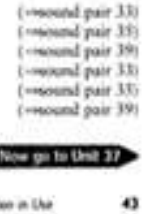

Appendix D. Instruction Material for Experimental Group

Choose the sentence you hear!

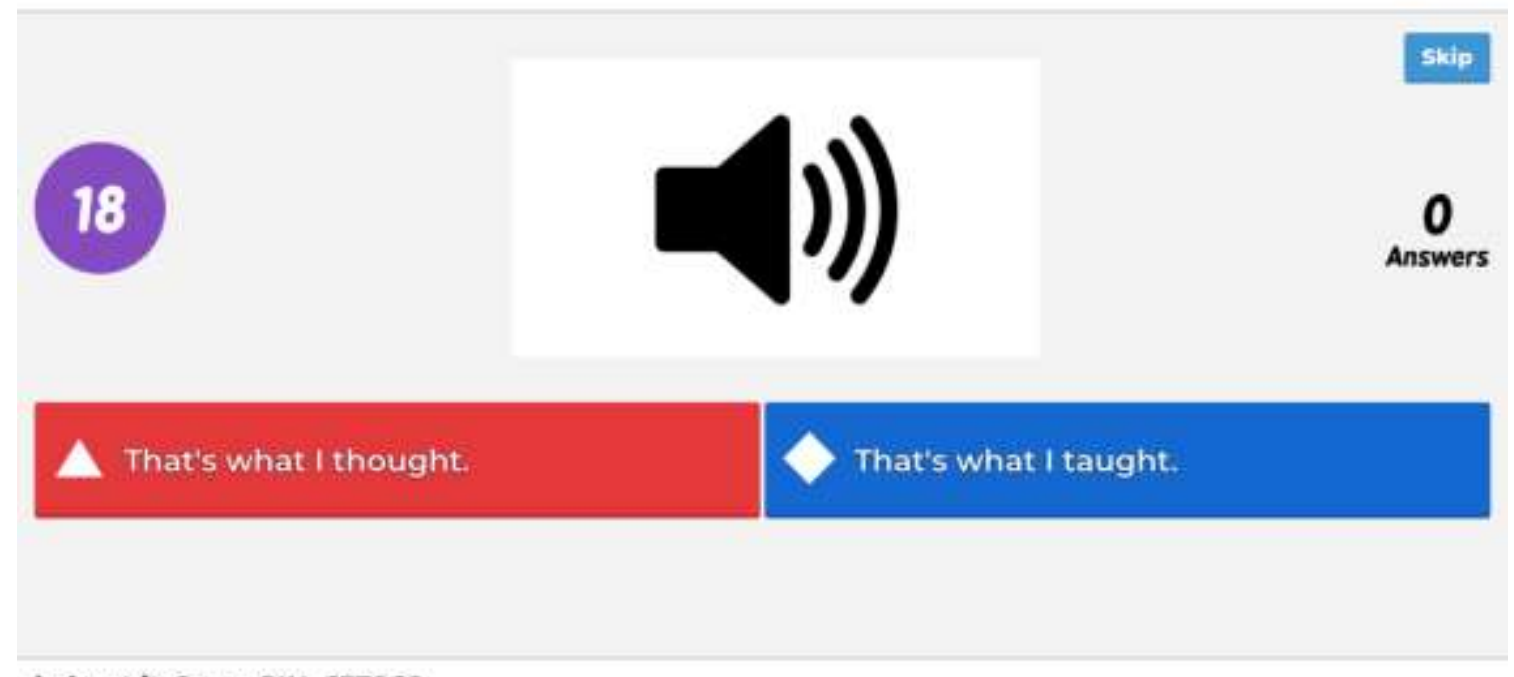

kahoot.it Game PIN: 637860 


\section{Choose the word you hear!}

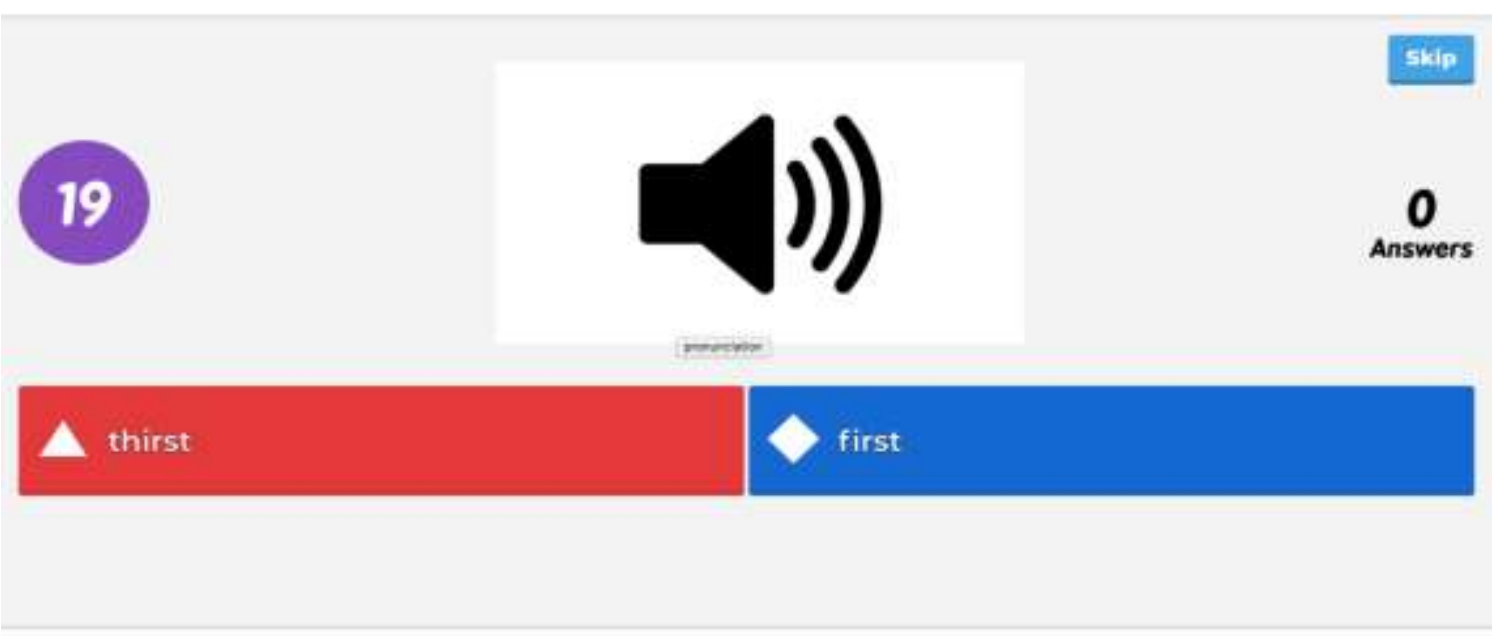

kahoot.it Game PIN: $\mathbf{8 3 8 3 4 8}$

\section{Telaffuz becerisi geliştirme tekniği olarak kahoot uygulamasının kullanımı}

\section{$\ddot{O} z$}

Telaffuz yabancı dil öğretiminde ve öğreniminde en temel sorunlardan biridir ve üzerinde yeterince durulmamaktadır. Çoğu öğrenci telaffuzun yabancı dilin diğer alanlarına kıyasla daha az önem taşıdığını düşünmektedir. Araştırmacıların çoğu neredeyse her seviyeden öğrenci üzerinde telaffuz zayıflığı ile ilgili araştırmalar yapmış, ancak bu araştırmaların yabancı dil öğrencilerinin telaffuzunu geliştimek için yeterli olmadığı saptanmıştır. Bu çalışma Kahoot uygulamasının yabancı dil telaffuzunu geliştirmedeki etkinliğini araştırmayı amaçlamaktadır ve çalışma Selçuk Üniversitesi Mütercim-Tercümanlık Bölümü ikinci sınıf öğrencilerine uygulanmıştır. Öncelikle katılımcıların telaffuzlarındaki hataları tespit etmek amacıyla bir hata bulma testi kullanılmıştır. Daha sonra, katlımcılardan Deney ve Kontrol grubu olmak üzere iki grup oluşturulmuştur. Telaffuz eğitimine başlamadan önce her iki gruba da ön-test verilmiş, sonrasında katılımcıların telaffuzunu geliştirmek amacıyla söylenişinde sorun yaşanabilecek olan seslerle ilgili alıştırmalar hedefe yönelik bir ders materyalinden takip edilmiştir. Çalışmanın deneysel bölümünde, bu alıştırmalar deney grubunda Kahoot uygulaması vasıtasıyla verlirken, buna karşılık kontrol grubunda ise sadece ders materyali içindeki aktiviteler takip edilmiştir. Daha sonra her iki gruba da çalışmanın son testi uygulanmıştır. Her iki yöntem arasındaki farklılıkların analizi için gruplar arası manidarlık testi (t-test) kullanılmıştır. Elde edilen sonuçlara göre telaffuz geliştirme aktivitesi olarak Kahoot uygulamasının kullamının daha etkin olduğu gözlemlenmiştir.

Anahtar Sözcükler: Kahoot uygulaması; telaffuz becerisi

\section{AUTHOR BIODATA}

Nurcihan Yürük has got bachelor's degree from Marmara University, Department of English Language Teaching in 2004. She has got her MA degree and Phd Degree from Hacettepe University Department of English Language Teaching. She has been continuing her academic life as an assistant professor at Selçuk University, Department of Translation and Interpretation. Her interest areas are foreign language teaching, teacher training material, translation and educational technology. 